\title{
Thermal Resistance of Spores of Two Species of the Genus Bacillus ${ }^{1}$
}

\author{
Fred Fernández-Coll and Wanda Rodríguez-Toro ${ }^{2}$ \\ ABSTRACT
}

Parameters that increased the thermal resistance of spores of Bacillus coagulans and Bacillus macerans, two common spoilage organisms in canned acid and acidified loods, were studied. Spores of these organisms were produced on solid media with various concentrations of added manganese, calcium chloride, or both, and at different $\mathrm{pH}$ values, and incubated at different temperatures. They were then heated in boiling water and decimal reduction times (D values) calculated. Results indicated that growing the organisms in nutrient agar modified with $50 \mathrm{p} / \mathrm{m}$ of $\mathrm{MnSO}_{4}, \mathrm{pH} 6.8$ and incubation temperature of $50^{\circ} \mathrm{C}$ produced spores with greatest heat resistance in both $B$. coagulans and $B$. macerans.

\section{INTRODUCTION}

According to regulations of the Food and Drug Administration, acid and acidified foods should be thermally processed to destroy the vegetative cells of microorganisms which are of public health and non-health significance, capable of reproducing in food under the conditions in which that food is stored, distributed, retailed and held by the user (5). This regulation does not provide for the destruction of spores of microorganisms that could survive, germinate and grow in these products, thus enhancing the probability of spoilage. Moreover, recent studies have indicated that growth of Bacillus licheniformis (10) and B. coagulans (2) could raise the $\mathrm{pH}$ of tomato products, thus posing a botulinal threat in these water-bath processed foods if the spores of such organisms are not destroyed in the thermal process. An acid food is safe from Clostridium botulinum if the heat process kills all organisms capable of growing at $\mathrm{pH} \leq 4.6$ and there is no post process contamination (11).

To establish a thermal process for a given food, we must first determine the thermal resistance of the most resistant microorganisms of significance in that product. However, before this resistance can be determined, spores with enhanced heat resistance should be obtained for the determination of these thermal processes to provide a safety margin.

Thermal resistance of spores is greatly affected both by conditions prevailing during sporulation and by conditions prevailing during the heat treatment $(1,6,13)$. Variation in resistance could also occur among

\footnotetext{
${ }^{1}$ Manuscript submitted to Editorial Board July 18, 1985.

${ }^{2}$ Assistant Food Microbiologist and former Graduate Student, Food Technology Laboratory, Agricultural Experiment Station, Mayagüez Campus, and Departament of Biology, University of Puerto Rico, Río Piedras P. R.
} 
different strains of a given bacteria, even when the spores are obtained from the same batch of sporulation medium.

Raising incubation temperature and altering the culture medium have both been commonly used to study bacterial spore thermal resistance. The literature reports that the higher the temperature at which the spores are produced, the higher their thermal resistance $(3,4,7,15)$. The effect of certain divalent cations on heat resistance of bacterial spores has also been studied $(1,8,9)$.

The present research comprises determination of conditions for enhancing thermal resistance of spores of Bacillus coagulans and B. macerans, two common spoilage bacteria in acid and acidified foods in hermetically sealed containers.

\section{MATERIALS AND METHODS}

Cultures of B. coagulans ATCC 8038 and B. macerans ATCC 7069 were inoculated onto nutrient agar (NA; Difco Laboratories, Detroit, Michigan $)^{3}$ modified with $7 \mathrm{p} / \mathrm{m}$ of $\mathrm{MnSO}_{4}$ and incubated at $35^{\circ}, 45^{\circ}$ and $50^{\circ} \mathrm{C}$; NA modified with 25,50 and $75 \mathrm{p} / \mathrm{m}$ of $\mathrm{MnSO}_{4}$ and incubated at $50^{\circ} \mathrm{C}$; NA modified with $50 \mathrm{p} / \mathrm{m}$ of $\mathrm{MnSO}_{4}$ and incubated at $55^{\circ} \mathrm{C}$; NA modified with $50 \mathrm{p} / \mathrm{m}$ of $\mathrm{MnSO}_{4}$ plus $50 \mathrm{p} / \mathrm{m}$ of $\mathrm{CaCl}_{2}$ and incubated at $50^{\circ} \mathrm{C}$; NA modified with $50 \mathrm{p} / \mathrm{m}$ of $\mathrm{CaCl}_{2}$ and incubated at $50^{\circ} \mathrm{C}$; NA modified with $50 \mathrm{p} / \mathrm{m}$ of $\mathrm{MnSO}_{4}, \mathrm{pH}$ adjusted to 6 and 8 and incubated at $50^{\circ} \mathrm{C}$. All cultures were incubated for 4 days. Different sets of cultures of both organisms were used to repeat all the above mentioned inoculations to obtain replicates of each test condition. Additional $B$. coagulans and $B$. macerans cultures, grown on NA modified with $7 \mathrm{p} / \mathrm{m}$ of $\mathrm{MnSO}_{4}$ and incubated at $35^{\circ} \mathrm{C}$, were prepared.

After incubation, cultures were suspended in sterile phosphate buffer $\left(0.07 \mathrm{M}\right.$ solutions of $\mathrm{KH}_{2} \mathrm{PO}_{4}$ and $\mathrm{Na}_{2} \mathrm{HPO}_{4}$ mixed to a $\mathrm{pH}$ of 7) to which 200 micrograms lysozyme $(41,100$ units $/ \mathrm{mg}$, grade 1, Sigma Chemical Co., St. Louis, Mo.) per milliliter of suspensions were added to destroy vegetative cells. Suspensions with added lysozyme were held at $35^{\circ} \mathrm{C}$ for $1 \mathrm{hr}$ to allow lysis of vegetative cells. The additional $B$. coagulans and $B$. macerans cultures were suspended in phosphate buffer and stored under refrigeration for 1.5 month to allow autolysis of vegetative cells.

Concentration of spores per milliliter of suspension was determined through a direct microscopic count, and each suspension subsequently diluted in sterile phosphate buffer to obtain a concentration of $10^{4}$ spores per $\mathrm{ml}$. One milliliter aliquots of each suspension were deposited into 75 $\times 100 \mathrm{~mm}$ sterile test tubes, which were then placed in a boiling water

\footnotetext{
${ }^{3}$ Trade names in this publication are used only to provide specific information. Mention of a trade name does not constitute a warranty of equipment or materials by the Agricultural Experiment Station of the University of Puerto Rico, nor is this mention a statement of preference over other equipment or materials.
} 
bath. At 2-min intervals for a period of $68 \mathrm{~min}$, duplicate tubes were withdrawn, the content diluted 10 times in sterile phosphate buffer, and $1 \mathrm{ml}$ of this dilution pour plated with Plate Count Agar (Difco Laboratories, Detroit, Michigan) and incubated at $35^{\circ} \mathrm{C}$ for 3 days. At the end of this incubation period, the number of colony forming units (CFU) was determined.

The log mean plate counts of both tubes in both duplicate test conditions were subjected to linear regression analyses. Decimal reduction times or D values (time, at a given temperature, required for $90 \%$ destruction of the existing population) were computed from the above information as the reciprocal of the regression coefficient (12). These D values were then subjected to analysis of variance to determine significant differences among test conditions and between organisms.

\section{RESULTS AND DISCUSSION}

The use of lysozyme to destroy vegetative cells does not significantly alter $(\mathrm{P}>0.05)$ the $\mathrm{D}$ values of the spores of both $B$. coagulans and $B$. macerans (produced at $35^{\circ} \mathrm{C}$ ) as compared to the ones obtained by autolysis of the vegetative cells (table 1). This fact allows for the rapid production of spore suspensions without concern about the effect lyso-

T'ABLE 1.-Decimal reduction times ( $D$ values) in minutes of spores of $B$. coagulants and $B$ macerans produced in madified nutrient agar and heated in boiling water

\begin{tabular}{|c|c|c|}
\hline Nutrient Agar modiffed with:, & B. coagulans & B. macerans \\
\hline $7 \mathrm{p} / \mathrm{m} \mathrm{MnSO}_{4}\left(35^{\circ} \mathrm{C}\right)^{3}$ & 26.3 & 13.5 \\
\hline $7 \mathrm{p} / \mathrm{m} \mathrm{MnSO} 4\left(35^{\circ} \mathrm{C}\right)$ & 25.6 & 13.7 \\
\hline $7 \mathrm{p} / \mathrm{m} \mathrm{MnSO}_{4}\left(45^{\circ} \mathrm{C}\right)$ & 30.3 & 22.7 \\
\hline $7 \mathrm{p} / \mathrm{m} \mathrm{MnSO}_{4}\left(50^{\circ} \mathrm{C}\right)$ & 34.5 & 23.3 \\
\hline $7 \mathrm{p} / \mathrm{m} \mathrm{MnSO},\left(55^{\circ} \mathrm{C}\right)$ & 22.2 & 23.8 \\
\hline $25 \mathrm{p} / \mathrm{m} \mathrm{MnSO}_{4}\left(50^{\circ} \mathrm{C}\right)$ & 70.0 & 61.0 \\
\hline $50 \mathrm{p} / \mathrm{m} \mathrm{MnSO}_{4}\left(50^{\circ} \mathrm{C}\right)$ & 80.2 & 80.5 \\
\hline $50 \mathrm{p} / \mathrm{m} \mathrm{MnSO}_{4}\left(55^{\circ} \mathrm{C}\right)$ & 51.6 & 48.4 \\
\hline $75 \mathrm{p} / \mathrm{m} \mathrm{MnSO}_{4}\left(50^{\circ} \mathrm{C}\right)$ & 56.7 & 71.9 \\
\hline $\begin{array}{c}50 \mathrm{p} / \mathrm{m} \mathrm{MnSO}_{4}+50 \mathrm{p} / \mathrm{m} \\
\mathrm{CaCl}_{2}\left(50^{\circ} \mathrm{C}\right)\end{array}$ & 57.0 & 55.4 \\
\hline $50 \mathrm{p} / \mathrm{m} \mathrm{CaCl}{ }_{2}\left(50^{\circ} \mathrm{C}\right)$ & 56.0 & 52.7 \\
\hline $\begin{array}{l}50 \mathrm{p} / \mathrm{m} \mathrm{MnSO}_{4}, \mathrm{pH} 6\left(50^{\circ}\right. \\
\quad \mathrm{C})\end{array}$ & 38.7 & 44.9 \\
\hline $\begin{array}{l}50 \mathrm{p} / \mathrm{m} \mathrm{MnSO} \\
\quad \mathrm{C})\end{array}$ & 36.4 & 19.1 \\
\hline
\end{tabular}

${ }^{1}$ The $\mathrm{pH}$ of the medium was $6.8-7.0$ unless otherwise specified.

${ }^{2}$ Number in parentheses indicates incubation temperature at which spores were produced.

${ }^{3}$ Free spores in this test condition were obtained by autolysis of the vegetative cells after 1.5 month refrigerated storage. In all other test conditions, free spores were obtained by treacment with lysozyme to destroy vegetative cells. 
zyme may have upon the thermal resistance of such spores, and without need of heating the suspension to destroy vegetative cells.

Increasing the incubation temperature at which the spores were produced resulted in differences in the $\mathrm{D}$ values obtained. In $B$. coagulans, the $\mathrm{D}$ value of spores significantly increased $(\mathrm{P} \leq 0.01)$ when the incubation temperature was raised from $35^{\circ}$ to $45^{\circ}$ to $50^{\circ} \mathrm{C}$. However, it significantly decreased ( $\mathrm{P} \leq 0.01$ when the temperature was raised from $50^{\circ}$ to $55^{\circ} \mathrm{C}$. For $B$. macerans spores, the $\mathrm{D}$ value significantly increased $(\mathrm{P} \leq 0.01)$ when the incubation temperature was raised from $35^{\circ}$ to $45^{\circ}$ $\mathrm{C}$, but there were no significant increases $(\mathrm{P}>0.05)$ when it was raised from $45^{\circ}$ to $50^{\circ}$ to $55^{\circ} \mathrm{C}$ (table 1).

Existing reports indicate there is an increase in thermal resistance of spores with an increase in the incubation temperature at which they are produced $(4,7)$. Other findings point out there is an optimum incubation temperature for the highest spore heat resistance, below or above which this thermal resistance diminishes (15). Our results support these latter findings.

Addition of $\mathrm{MnSO}_{4}$ to the culture medium in concentrations above 7 $\mathrm{p} / \mathrm{m}$ increased the thermal resistance of spores of both bacteria above that found when this concentration was added. When the spores of $B$. coagulans were tested, the $\mathrm{D}$ values obtained when $25 \mathrm{p} / \mathrm{m}$ of $\mathrm{MnSO}_{4}$ was added to the medium were significantly higher $(\mathrm{P} \leq 0.01)$ than when 7 $\mathrm{p} / \mathrm{m}$ was used (table 1 ). When $50 \mathrm{p} / \mathrm{m}$ of $\mathrm{MnSO}_{4}$ was added, the $\mathrm{D}$ values of spores were significantly higher $(P \leq 0.01)$ than when $25 \mathrm{p} / \mathrm{m}$ was used, but when $75 \mathrm{p} / \mathrm{m}$ of $\mathrm{MnSO}_{4}$ was added to the culture medium the $D$ values were significantly lower $(P \leq 0.01)$ than when 25 or $50 \mathrm{p} / \mathrm{m}$ concentrations were used, although they were significantly higher $(\mathrm{P} \leq$ 0.01 ) than when $7 \mathrm{p} / \mathrm{m}$ of $\mathrm{MnSO}_{4}$ was added to the medium. All spores in these test conditions were produced at $50^{\circ} \mathrm{C}$. When spores were produced in NA with $50 \mathrm{p} / \mathrm{m}$ of $\mathrm{MnSO}_{4}$ added and incubated at $55^{\circ} \mathrm{C}$, the $D$ values were significantly lower $(P \leq 0.01)$ than when incubated at $50^{\circ} \mathrm{C}$ with the same amount of added $\mathrm{MnSO}_{4}$. With the spores of $B$. macerans, similar results were obtained except that when $75 \mathrm{p} / \mathrm{m}$ of $\mathrm{MnSO}_{4}$ was added to the medium, the $\mathrm{D}$ values were significantly higher $(\mathrm{P} \leq 0.01)$ than the ones obtained when $25 \mathrm{p} / \mathrm{m}$ was used.

These results indicate that the addition of $50 \mathrm{p} / \mathrm{m}$ of $\mathrm{MnSO}_{4}$ to NA resulted in production of spores with maximum heat resistance as compared to the other concentrations used. When this same $\mathrm{MnSO}_{4}$ concentration was used and plates incubated at $55^{\circ} \mathrm{C}$, the spore $\mathrm{D}$ value obtained was significantly lower $(\mathrm{P} \leq 0.01)$ than when incubated at $50^{\circ} \mathrm{C}$, both for $B$. coagulans and $B$. macerans. This confirms our previous finding that there is an optimum temperature for the production of spores with optimum heat resistance. 
Under these circumstances (NA plus $50 \mathrm{p} / \mathrm{m}$ of $\mathrm{MnSO}_{4}$ and incubation temperature of $50^{\circ} \mathrm{C}$ ) the $\mathrm{D}$ value of the spores of $B$. macerans was not significantly different $(\mathrm{P}>0.05)$ from that of the spores of $B$. coagulans. When $75 \mathrm{p} / \mathrm{m}$ of $\mathrm{MnSO}_{4}$ was added to NA (incubation temperatures of $\left.50^{\circ} \mathrm{C}\right)$ the D value of the spores of $B$. macerans was significantly higher $(\mathrm{P} \leq 0.01)$ than that for the spores of $B$. coagulans. The spores of $B$. coagulans are described as being more heat resistant than the spores of $B$. macerans (14). Our finding indicates that, under certain circumstances, the spores of $B$. macerans could be equally as, or even more heat resistant, than the ones of $B$. coagulans. This is a fact to be considered when the thermal destruction of potential spoilage organisms is sought in acid or acidified foods.

Using another divalent cation, namely calcium, in conjunction with or instead of manganese, resulted in reduced spore heat resistance as compared to the resistance when $50 \mathrm{p} / \mathrm{m}$ of $\mathrm{MnSO}_{4}$ alone was added to the culture medium on which the spores were produced. For both $B$. coagulans and $B$. macerans spores, the D values obtained when a mixture of $50 \mathrm{p} /$ $\mathrm{m}$ of $\mathrm{CaCl}_{2}$ plus $50 \mathrm{p} / \mathrm{m}$ of $\mathrm{MnSO}_{4}$ or when $50 \mathrm{p} / \mathrm{m}$ of $\mathrm{CaCl}_{2}$ alone (incubation at $50^{\circ} \mathrm{C}$ ) was added to $\mathrm{NA}$, were significantly lower $(\mathrm{P} \leq$ 0.01) than the ones obtained when $50 \mathrm{p} / \mathrm{m}$ of $\mathrm{MnSO}_{4}$ alone (incubation at $50^{\circ} \mathrm{C}$ ) was added to the medium (table 1). These results are consistent with previous reports (1). The D values of the spores of $B$. coagulans exhibited no significant difference $(\mathrm{P}>0.05)$ in heat resistance when 50 $\mathrm{p} / \mathrm{m}$ of $\mathrm{CaCl}_{2}$ plus $50 \mathrm{p} / \mathrm{m}$ of $\mathrm{MnSO}_{4}$ or when $50 \mathrm{p} / \mathrm{m}$ of $\mathrm{CaCl}_{2}$ alone was added to NA, whereas the spores of $B$. macerans were significantly ( $P \leq$ 0.01) more heat resistant when the mixture rather than $\mathrm{CaCl}_{2}$ alone was added to the culture medium. However, these $\mathrm{D}$ values obtained (for both types of spores) when calcium was added to NA, either alone or combined with $\mathrm{MnSO}_{4}$, were significantly higher $(\mathrm{P} \leq 0.01)$ than the ones obtained when $7 \mathrm{p} / \mathrm{m}$ of $\mathrm{MnSO}_{4}$ (with incubation at $50^{\circ} \mathrm{C}$ ) was added.

These results demonstrate that both the type and quantity of divalent cation present in the medium are of extreme importance in enhancing the thermal resistance of these bacterial spores. There are some cations (in this case manganese) that show greater capability than others (namely calcium) to increase the thermal resistance of spores. As with temperature, there seems to be an optimum cation concentration required, below or above which the increase in spore thermal resistance diminishes.

The spores of $B$. macerans showed no significant difference $(P>0.05)$ in their heat resistance as compared to the ones of $B$. coagulans when they were both produced in NA with $50 \mathrm{p} / \mathrm{m}$ of $\mathrm{CaCl}_{2}$ plus $50 \mathrm{p} / \mathrm{m}$ of $\mathrm{MnSO}_{4}$ added and incubated at $50^{\circ} \mathrm{C}$. This again indicates that under certain conditions, the spores of both bacteria can be equally resistant to heat. 
Altering the $\mathrm{pH}$ of $\mathrm{NA}$ (with $50 \mathrm{p} / \mathrm{m}$ of $\mathrm{MnSO}_{4}$ added and incubated at $50^{\circ} \mathrm{C}$ ) resulted in a decrease in the thermal resistance of the spores produced on it. Lowering the medium $\mathrm{pH}$ to 6 (from its natural 6.8-7.0 value) or raising it to 8 resulted in spores with a $D$ value significantly lower ( $\mathrm{P} \leq 0.01$ ) than that obtained when the $\mathrm{pH}$ was not changed (table 1). This held true for both test organisms. The $\mathrm{pH}$ of the medium is therefore another important parameter to be considered in the production of spores with elevated heat resistance. The alteration of $\mathrm{pH}$ in what could be considered an otherwise adequate medium and conditions for production of heat resistant spores could result in a complete loss of the capacity of that medium to carry out its intended function.

When the $\mathrm{pH}$ of the medium was lowered to a value of 6 , the spores of $B$. macerans exhibited a $\mathrm{D}$ value that was significantly higher $(\mathbf{P} \leq 0.01)$ than the one of the spores of $B$. coagulans. It is thus again demonstrated that under certain conditions, the spores of $B$. macerans could be more heat resistant than (or at least equal to) the spores of $B$. coagulans.

The combination of NA modified with $50 \mathrm{p} / \mathrm{m}$ of $\mathrm{MnSO}_{4}, \mathrm{pH} 6.8-7.0$ and incubation at $50^{\circ} \mathrm{C}$ produced the most heat resistant spores in both microorganisms tested. Under these optimized conditions, the spores of $B$. coagulans and $B$. macerans possessed a heat resistance that was not significantly different from that of the other. Both these findings must be kept under consideration when inoculation studies are carried out either to determine or to confirm a thermal process in canned acid or acidified foods.

\section{RESUMEN}

Para este estudio se utilizaron dos bacterias que comúnmente crecen en los alimentos ácidos y los deterioran: Bacilus coagulans y $B$. macerans. Se estudió el efecto de ciertos parámetros sobre la resistencia térmica de dichas esporas. Los cultivos se sembraron en agar nutritivo (DIFCO) modificado con 25, 50 y 75 ppm de $\mathrm{MnSO}_{4}$ e incubados a $50^{\circ} \mathrm{C} ; 50 \mathrm{ppm}$ $\mathrm{CaCl}_{2}+50$ ppm $\mathrm{MnSO}_{4}$ e incubado a $50^{\circ} \mathrm{C} ; 50 \mathrm{ppm} \mathrm{MnSO}_{4}$ y el pH ajustado a 6 y a 8 con $\mathrm{HCl} 1 \mathrm{~N}$ y $\mathrm{NaOH} 1 \mathrm{~N}$ respectivamente; y con $50 \mathrm{ppm}$ $\mathrm{MnSO}_{4}$ e incubado a $55^{\circ} \mathrm{C}$.

Luego de 3 días de incubación, los cultivos se mantuvieron en una solución amortiguadora de fosfato estéril y se trataron con lisozima para destruir las células vegetativas. Se determinó microscópicamente la concentración de esporas, se diluyó correspondientemente hasta obtener una concentración de $10^{4}$ esporas $/ \mathrm{ml}$, se vertieron porciones de $1 \mathrm{ml}$ en pequeños tubos de ensayo, y se calentaron en agua hirviente por espacio de 68 minutos. Cada 2 minutos se extrajeron tubos en duplicado y se hicieron conteos de placa. 
Los resultados indicaron que las esporas producidas con $50 \mathrm{ppm}$ de $\mathrm{MnSO}_{4}$ fueron más resistentes que las producidas con 25 o $75 \mathrm{ppm}$. Esto fue cierto con ambos organismos. El añadir $50 \mathrm{ppm}$ de $\mathrm{CaCl}_{2}$ o una combinación de $50 \mathrm{ppm}$ de $\mathrm{CaCl}_{2}+50 \mathrm{ppm}$ de $\mathrm{MnSO}_{4}$ al medio, produjo esporas que eran menos resistentes que las producidas con $50 \mathrm{ppm}$ de $\mathrm{MnSO}_{4}$. El variarle el pH al medio de $50 \mathrm{ppm}$ de $\mathrm{MnSO}_{4}$ hasta valores de 6 y 8 dio como resultado esporas con menor resistencia térmica que las producidas en el medio con el $\mathrm{pH}$ normal. Utilizar el agar nutritivo con 50 ppm de $\mathrm{MnSO}_{4}$ y pH normal con incubación a $55^{\circ} \mathrm{C}$ produjo esporas con menor resistencia térmica que cuando se incubó a $50^{\circ} \mathrm{C}$.

Se encontró que la combinación que produjo esporas con resistencia térmica máxima, en ambas bacterias, fue utilizar agar nutritivo con $50 \mathrm{ppm}$ de $\mathrm{MnSO}_{4}, \mathrm{pH}$ de 6.8 a 7.0 e incubación a $50^{\circ} \mathrm{C}$. Existe una temperatura óptima de incubación, por encima de la cual la resistencia térmica de las esporas queda igual o disminuye. Bajo ciertas condiciones las esporas de $B$. macerans fueron tan resistentes al calor o más que las de $B$. coagulans, observación que no se habia informacdo hasta la fecha.

\section{LITERATURE CITED}

1. Amaha, M. and Ordal, Z. J., 1957. Effect of divalent cations in the spororulation medium on the thermal death rate of Bacillus coagulans var. thermoacidurans, $J$, Bacleriol, 74: 596-604.

2. Anderson, R. E., 1984. Growth and corresponding elevation of tomato juice $\mathrm{pH}$ by Bacillus coagulans, J. Food Sci. 49: 647-649.

3. Curran, H. R., 1935. The influence of some environmental factors upon thermal resistance of bacterial spores, J. Infect. Dis. 56: 196-202.

4. El-Bisi, H. M. and Ordal, Z. J., 1956. The effect of sporulation temperature on the thermal resistance of Bacillus coagulans var. thermoacidurans. J. Bacteriol. 71: 1016.

5. Food and Drug Administration, 1979. Code of Federal Regulations, Title 21, Parts 100 to 199, Office of the Federal Register, National Archives and Records Service, General Services Administration, Washington, D.C.

6. Gombas, D. E., 1983. Bacterial spore resistance to heat, Food Technol. 37 (11): 105110.

7. Lechowich, R. V. and Ordal, Z. J., 1962. The influence of the sporulation temperature on the heat resistance and chemical composition of bacterial spores, Can. J. Microbiol. 8: 287-295.

8. Mayou, J. L. and Jezeski, J. d., 1977. Effect of using milk as heating menstruum on the apparent heat resistance of Bacillus stearothermophilus spores. J. Food Prot., 40: 228-231.

9. Mayou, J. L. and Jezeski, J. J., 1977. Effect of sporulation media on the heat resistance of Bacillus stearothermophilus spores. J. Food Prot. 40: 232-233.

10. Montville, T. J., 1982. Metabiotic effect of Bacillus licheniformis on Clostridium botulinum: implications for home canned tomatoes. Appl. Environ. Microbiol. 44: 334-338.

11. Odlaug, T. E. and PIlug, I. J., 1978. Clostridium bolulinum and acid foods. J. Food Prot. 41; 566-573. 
12. Reynolds, H. and Lichtenstein, H., 1952. Symposium on the biology of bacterial spores. Part VIII. Evaluation of heat resistance data for bacterial spores, Bacteriol. Rev. 16: $126-135$

13. Roberts, 'T'. A. and Hitchins, A. D., 1969. Resistance of spores. Ch. 16. In The Bacterial Spore, G. W. Gould and A. Hurst (Ed) p. 611, Academic Press, New York, N.Y.

14. Stumbo, C. R., 1973. Thermobacteriology in Food Processing, 2nd ed, Academic Press, New York, N.Y.

15. Sugiyama, H., 1951. Studies on the factors affecting the heat resistance of spores of Clostridium botulinum. J. Bacteriol. 62: 81-96. 